\title{
IAMJ
}

INTERNATIONAL

AYURVEDIC

MEDICAL JOURNAL

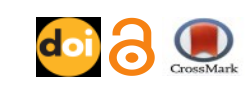

Review Article

ISSN: 23205091

Impact Factor: 5.344

\section{COSMETIC EFFECT OF DINACHARYA (DAILY ROUTINE) PROCEDURES - A CRITICAL REVIEW}

\author{
Ripsa Raj K. P1 , P Sudhakar Reddy ${ }^{2}$ \\ ${ }^{1}$ IIP.G Scholar, Department of P G Studies in Swasthavritta, JSS Ayurveda College, Mysuru, Karnataka, India \\ ${ }^{2}$ Professor \& Head, Department of P G Studies in Swasthavritta, JSS Ayurveda Medical College, \\ Lalithadripura Road, Mysuru -570028 Karnataka, India
}

Email: drpsreddy05@yahoo.com

\section{https://doi.org/10.46607/iamj1708082020}

(Published online: August 2020)

Open Access

(C) International Ayurvedic Medical Journal, India 2020

Article Received:07/07/2020 - Peer Reviewed:27/07/2020 - Accepted for Publication:27/07/2020

(D) Check for updates

\section{ABSTRACT}

Beauty is the desire of every individual to give pleasure to the sense.The Federal Food, Drug, and Cosmetic Act (FD\&C Act) defines cosmetics by their intended use, as "articles intended to be rubbed, poured, sprinkled, or sprayed on, introduced into, or otherwise applied to the human body for cleansing, beautifying, promoting attractiveness, or altering the appearance". Under this law cosmetics must not adulterate or misbranded. The cosmetic preparations are used for worship and for sensual enjoyment in India since Vedic period. The cleansing, beautifying and attractiveness effects are described in Ayurveda extensively. Swasthavritta, the preventive principles of Ayurveda laid down rules and regulations like Dinacharya (Daily routine), Ritu chary (Seasonal regimen), Sadvritta (Good conducts of life) etc, to be followed by a healthy person. Among these the practices of daily routines are very much relevant in promoting cosmetic effect which is reviewed in this article.

Keywords: Dinacharya, Cosmetics, Ayurveda

\section{INTRODUCTION}

Beauty is often involving an interpretation of some entity as being in balance and harmony with nature which may lead to feeling of attraction and emotional well-being. ${ }^{1}$ It is the desire of every individual to give pleasure to the sense. The word 'cosmetics' means, any substance used to clean, improve, or change the complexion of skin, hair, nails, teeth, or eyes. It includes beauty preparations and grooming aids. Ayur- 
veda is a science of life, apart from curing diseases, it says all about how to maintain a good physic as well as a sound mind. Both are ultimately linked together like bow and the arrow. Ayurvedic view of cosmetics is related to the healthy status of body as well as mind.

\section{Cosmetics}

It is the substances intended to be applied to the human body for cleaning, beautifying, promoting attractiveness or altering the appearance without affecting the body structure or functions. It is derived from the Greek word 'kosmetikos' which means beautifying ${ }^{2}$. The word beautifying resembles correcting the defects especially of the face. Cosmetology is the branch of science which deals with the study and application of beauty treatment. Cosmetics have been used for thousands of years, the civilization and cosmetology have interrelationship and have social impact since the ancient period. The primary known individuals who utilized cosmetics to upgrade their beauty were Egyptians. They were very fond of eyeliner and eye shadows in dark colors including blue, red, and black. Sumerians are the first to invent and wear lipstick about 5000 years ago. $3000 \mathrm{BC}$ to $1500 \mathrm{BC}$ women in ancient Indus valley civilization applied red tinted lipsticks for face decoration. Skin creams made of bee wax, olive oil and rose water described by Romans.840BC ancient Greeks used cosmetics mentioned as,' old testament' for painting eyelids.

Ayurvedic literature and other ancient allied texts provide us knowledge regarding cosmetics. Pre-vedic kala (Mohenjo-Daro and Harappa), Vedic kala, Puranic kala, Samhita kala, Madhyakala, and other ailed texts like Kautilya Arthasastra (350- 283 BC), Kamasutra (100- $200 \mathrm{CE})$, Abhigyana shakumtalam (375$415 \mathrm{CE}$ ), are provide the details regarding the cosmetics used by Indian territories ${ }^{3}$. One of the most popular traditional Chinese medicine is the 'Fungus Tremella Fuciformis', used as a beauty product by women in China and Japan. Numerous social steps made in the late 1800's and mid 1900's, dark skin was yet considered as unfortunate, so makeup was frowned up on in general. In $19^{\text {th }}$ century most of the ladies always aimed to look pale and interesting. $20^{\text {th }}$ century cosmetics widespread use by women in nearly all industrial societies around the world. In the beginning of $21^{\text {st }}$ century cosmetics industry become a multibillion Dollar enterprise. The history says that from the time of Ancient period itself cosmetics place an important role in men's life and herbal combinations are used widely. Cosmetics there are two categories of personal care products. The Federal food, drug and cosmetic act define cosmetics as products intended to cleanse or beautify. A separate category exists for medications which are intended to diagnose, cure, mitigates, treat or prevent disease or affect the structure or function of the body. A variety of organic and inorganic compounds comprises typical cosmetics. The cosmetic products that can be applied to the face - skin care creams, lipsticks, eye and facial make up, novelettes, and colored contact lenses, to the body deodorants, lotions, powders, perfumes, body products, bath oils, bubble baths, bath salts, and body butters, to the hand and nails finger nail and toe nail polish and hand sanitizer, to the hair permanent chemicals, hair colors, hair sprays and gels ${ }^{4}$.

\section{Dinacahrya as Cosmetics}

Dinacharya (daily regimen) is whatever the activities completed by an individual from the time of waking up in the morning till one goes to his bed in the night ${ }^{5}$. Ayurveda emphasize importance of Dinacharya for the maintaining physiological and psychological health, and it is also for the Ehaloka (to this world) and Paraloka (for the life after death) life. Acharya's reveal the importance of Dinacharya, so they mentioned in separate chapter for Dinacharya in Brihatrayies. In this some of them have cosmetic effect.

Table 1: Dinacharya procedure and their cosmetic effects

\begin{tabular}{|l|l|l|}
\hline S.No & Dinacharya Procedure & Cosmetic effect \\
\hline 1 & $\begin{array}{l}\text { Ushajalapana }^{6} \text { (drinking water in } \\
\text { early morning) }\end{array}$ & Improves the eyesight, prevents early graying and hair fall and Intelligence \\
\hline 2 & \begin{tabular}{l} 
Mukha prakshalana (washing the \\
\hline
\end{tabular} & Removes the Neelika (blue moles), Pitaka (acne vulgaris), Vyanga (facial mela- \\
\hline
\end{tabular}




\begin{tabular}{|c|c|c|}
\hline & face) & $\begin{array}{l}\text { nosis), and helpful for easy and strong vision. It gives Seetatwa (coldness) to the } \\
\text { eyes. Dust particle will remove from face and skin become soft and shiny. It } \\
\text { prevents lips from cracking. Prevents dryness of face. }\end{array}$ \\
\hline 3 & $\begin{array}{l}\text { Anjana }^{8} \text { (Application of collyri- } \\
\text { um) }\end{array}$ & $\begin{array}{l}\text { Vision become clear and the eye shining just as the moon shining in the clear } \\
\text { sky. Makes eyes beautiful. }\end{array}$ \\
\hline 4 & $\begin{array}{l}\text { Dantadhavana\&Jihwanirlekhana }{ }^{9} \\
\text { (Tooth brushing and tongue } \\
\text { scraping) }\end{array}$ & Removes the dirt from teeth, promotes good smell and gladness. \\
\hline 5 & $\begin{array}{l}\text { Gandusha } \\
\text { gargle) }\end{array}$ & $\begin{array}{l}\text { Provides firmness to the teeth and removes the stiffness of the mouth. } \\
\text { It strengthens the muscles of cheek and face. Prevents the cracking of lips }\end{array}$ \\
\hline 6 & $\begin{array}{l}\text { Pratimarsa Nasya }{ }^{11} \text { (instilling two } \\
\text { drops of oil into each nostril) }\end{array}$ & $\begin{array}{l}\text { Prevents graying of hair and hair fall. Hair grows abundantly. Face becomes } \\
\text { cheerful. Delays old age changes and makes person looks younger. Skin, shoul- } \\
\text { ders, neck, face and chest become thick well developed and bright, sense organs } \\
\text { become strong, }\end{array}$ \\
\hline 7 & $\begin{array}{l}\text { Dhoomapana }{ }^{12} \text { (Medicated smok- } \\
\text { ing) }\end{array}$ & $\begin{array}{l}\text { It removes the foul smell of nose and mouth, prevents baldness, matting, falling } \\
\text { of hair, and provides more strength to the hair, cheeks and Sense organs. }\end{array}$ \\
\hline 8 & Abhyanga ${ }^{13}$ (oil massage) & Provide good luster to skin, improve skin complex \\
\hline 9 & Shiroabhyanga ${ }^{14}$ (Head massage) & $\begin{array}{l}\text { Prevents baldness and premature graying of hair. Promotes hair growth, hair } \\
\text { becomes thick and deep rooted. Face becomes glow. }\end{array}$ \\
\hline 10 & Snana $^{15}$ (Bath) & Eliminates bad odor, impurities from the body and promotes skin complexion. \\
\hline 11 & Vastradharana $^{16}$ (Wearing cloth) & Enhance the bodily charm, reputation in the society, brings good looking. \\
\hline 12 & Padabhyanga ${ }^{17}$ (Foot massage) & $\begin{array}{l}\text { Removes hardness and roughness in the feet and prevents cracking of the feet. } \\
\text { Promotes eyesight. }\end{array}$ \\
\hline 13 & Kesha prasadana ${ }^{18}$ (Combing) & $\begin{array}{l}\text { Promotes hair growth, prevents accumulation of dust and growth of germs on } \\
\text { scalp }\end{array}$ \\
\hline 14 & Udvartana $^{19}$ (Powder massage) & $\begin{array}{l}\text { It stabilizes body parts and provides brilliance to skin, removes the bed smell of } \\
\text { the body and uncomfortable feeling by sweat. Face become brighter with no } \\
\text { pigmentation, cheeks develop muscle and resembling like a lotus. }\end{array}$ \\
\hline 15 & $\begin{array}{l}\text { Anulepana }^{20} \text { (External applica- } \\
\text { tions) }\end{array}$ & $\begin{array}{l}\text { Eliminates sweat, foul smell, and abnormality of complexion. Improves glow of } \\
\text { the skin }\end{array}$ \\
\hline 16 & $\begin{array}{l}\text { Mukha lepa } a^{21} \text { (Application on } \\
\text { face) }\end{array}$ & $\begin{array}{l}\text { Eyes become firm, cheek and face corpulent, face will free from Acne (Pimples) } \\
\text { and makes face look handsome. }\end{array}$ \\
\hline 17 & $\operatorname{Ahara}^{22}$ (Food) & $\begin{array}{l}\text { Food gives Complexion, clarity, good voice, longevity, intelligence, happiness, } \\
\text { satisfaction, nourishment, strength\& intellect }\end{array}$ \\
\hline
\end{tabular}

\section{DISCUSSION}

Ayurvedic cosmetology starts from mother's womb, Dinacharya (Daily routine), Ratricharya (night regimen), Ritucharya (seasonal regimen), with the practice of medicinal herbs and minerals. Diet and lifestyle have special effect to improve and maintain beauty of an individual. Dinacharya gives the cosmetological effect for long term. Dantadhavana, Jihwa nirlekhana, Gandusha dharana, Mukha prakshalana helps to maintain facial structures. Abhyanga and its types nourish the skin and body. Udwartana gives firmness and removes tenderness of skin. Nasya increases tone of skin. Anjana and Netra prakshlana brighten the vision and cleanses, eyelashes and eyelids will attain the predominance. Ahara place a vital role in maintaining physical and mental health.

Mukhasodhana: which means the removal of dirt from the facial part, Mukha prakshalana, Danta dhavana, Jihwa nirlekhana, Tamboola sevana, Gandusha, Kavala are coming under this. Mukha prakshalana, Danta dhaavana removes the dirt in teeth, gives clarity, Sugandha (good smell), laghutva (lightness), and soumanasya (causing gladness). Due to Jihwanirlekhana mouth become clean and light. Tamboolasevana 
is Mukha vaisadhya (cleanses the oral cavity), Sougandhya kara (pleasant smell in mouth) and Kantikara (beautifying) to the face. It removes the dirt of Hanu (jaw), Danta (teeth). It is Hrudya (pleasing to mind)and removes the excessive salivation. Gandusha provides firmness to the teeth and removes the stiffness of the mouth. It strengthens the muscles of cheek and face. The cosmetics products like lipstick, lip gloss, lip liner, lip plumber, lip balm, lip stain, lip conditioner, lip primer, lip boosters and lip butters are given color, gloss, luster, and matte look to the lips. Primer creates an even tone throughout the skin and make up lasts longer. Concealed covers imperfections of the skin. Foundation is used to smooth out the face by covering spots, acne, blemishes, or uneven skin tone. Create a dewy look or a smoother finish. Face power is used to bake the foundation, so that it stays longer and give a matte finish. Rouge, blush or blusher is cheek coloring. Make the cheek bones appear more defined. Highlight is used to draw attention to the high points of the face it contains substance to provide shimmer. Bronzer enhances the color of the face and gives a natural look. These are the cosmetic products used daily to enhance the beauty of face instead of doing Mukha sodhaka procedures. Smile is the person's ability to express the range of emotions with the structure and movement of teeth and lips. So, to keep oneself confident, proper care of teeth and lips is needed ${ }^{23}$.

Care of eyes: Anjana and Netraprakshalana are the Dinacharya procedures coming under this. Anjana in ancient scriptures like Abhigyana Sakunthala and Meghadootam of kalidasa and many mythological epics encompasses the reference of cosmetic like Kajal itself which show the importance of Anjana. Acharya Caraka mentioned that Souviranjana (collyrium) is beneficial for eye, so it should be applied daily and Rasanjana (mercurial collyrium) should be applied once in five or eight days in order to drain out kapha and the waste material. Vision becomes clear and the eye shining just as the moon shining in the clear sky. It removes the Daha (burning), Kandu(itching) and Malas (dirt) and eliminates watering and pain of eye. It provides tolerance to wind and sun. And prevent eye diseases. Presently in market SURMA (Black Surma) is available in a glass bottle along with small glass rod for application which can be applied daily to get cosmetic effect of Anjana. Netra prakshalana with Lodra Kashaya (decoction of Symplocos recemosa) or Amalaka Swarasa (juice of Indian gooseberry) or cold water will remove the dryness of face and disease vitiated by Rakta and Pitta. The cosmetics used in eyes are-Mascara is used to darken, lengthen, thicken or draw attention to the eye lashes. Eye shadows are used to accentuate the eye area traditionally on, above and under the eyelids. Eye liner will enhance and elongate the apparent size or depth of the eye. Eyebrow pencils, creams, waxes, gels, and powders to color, fill in and define the brows. Anjana and Netra prakshalana have the cosmetic effects that penetrate through the optical nerve and strengthen the supply of optical arteries which will give rise to long lasting shyness and glacises to the eye ${ }^{24}$.

Abhyanga $^{25}$ (massage): skin is the largest organ, which separate individual from external environment. Oil get absorb the spores of skin and spread the whole body. It consists of Pada abhyanga and Siro abhyanga, the skin become well by anointing with the oil. It wards of the old age, exertion and Vata and bestows good vision, nourishment to the body, long life, good sleep, good and strong skin. Provide cleanliness, complexion, strength and pleasing appearance. Pada abhyanga (massage on feet) removes the Kharatva (hardness), Stabdhata, Roukshya (roughness), Srama (exertion) and Suptatva (numbness) of feet, and become soft, strong and steady. It should be use 3 times for cracks etc. developing the feet. Siroabhyanga (Massage on head) eliminates disease of head and strengthen all sensory organs. Hair becomes soft, lengthier, luxuriance, gloss, and black in color. It brings charming to the face, saturation in sense organ. Acharya Vagbhata mentioned for the proper nourishment of skin Abhyanga should be done 400 Matra kala (approximately 133 seconds) and it shows the direct effect on skin, layers of the skin should be nourished by this and removes all unwanted materials, and dead cells. The appearance should be changed and more grace on face, person is confident about his gust- 
ier and appearance body parts should be well identical.

Murdhataila (oiling the head): it prevents early occurrence of baldness, grey hair, falling of teeth, bones of skull become strong, provides long, black and firm rooted hair. Skin and face will be fine and sense organs become efficient. Oil penetrates through the scalp skin and pacifies the vitiated vata and pitta and penetrates to the pituitary gland to control all endocrine system in the body.

Nasya: Acharya Charaka explained in the contest of Dinacharya Nasya only indicated in Pravrti (forepart of rainy season), Sarat (autumn), and Vasanta (spring) Ritus $^{26}$. Which are coming under the Sadharana Ritu. It is administered to those who lead a happy life even during unsuitable time. Pratimarsa nasya is indicated for daily. Skin, shoulders, neck, face and chest become thick, well developed and bright, sense organs become strong, hair and mustaches do not become grey or brown, it does not fall of but grow and signs of old age do not gain strength. Nasya drugs reaches the brain and controlling different important functions of neurological, endocrine and circular systems. Through the vascular path of transportation nasal venous blood pooling into the facial veins. Facial veins have no valves it freely communicates with the intracranial circulation. Thus, from this path of circulation the facial parts will nourish ${ }^{27}$.

Udvartana (powder massage): It stabilizes body parts and provides brilliance to skin, removes the bed smell of the body and uncomfortable feeling by sweat. Face become brighter with no pigmentation, cheeks develop muscle, and resembling like a lotus. It is done with Pratiloma Kharshana (friction against the hair follicle), directly affect the circulatory system and enhance the circulation by reducing body fat, sweat gland function also enhances.
Dhoomapana (smoking): Acharya Charaka mentioned Prayogika dhoomapana for daily inhalation for healthy individual. It removes the foul smell of nose and mouth, pallor of face, baldness, matting, falling of hair, provides more strength to the hair, cheeks and Sense organs. Due to Sukshmma Guna of Dhooma it enters the smallest parts, Ushna(hot) and TeekshnaGuna liquefies the Doshas and eliminates. Gaseous form of medicines increases the bioavailability and the pressure variation will help to absorb $\mathrm{it}^{28}$.

Snana (Bath): Bathing is purifying, aphrodisiac, life promoting, destroys the fatigue, sweat \&dirt. Promotes strength, compactness and at the same cures tiredness, sweat and impurities of the body. Warm water (ushnodaka) is considered best for Snana.

Anulepana(applications fragrances to the body): Acharyas mentioned some herbal preparation which is Varnakara, eliminates sweat, foul smell, and abnormality of complexion especially Chandana (Sandal wood) or Agaru (Aquilaria agallocha).

Mukhalepa: These are the external applications for face, by this eye become firm, cheek and face corpulent, face will free from Vyanga and Pitaka, and handsome like lotus.

Ahara: Food helps to sustain living beings. All living beings in the world require food for Complexion, clarity, good voice, longevity, intelligence, happiness, satisfaction, nourishment, strength, \& intellect ${ }^{29}$. Its timely intake is the best habit for the healthy individuals, and it must be based on "Ashta ahara vidhi visesha ayatana". In the contest of Ahara, more intake of Lavana Rasa (salt) in diet leads to the early graying of hair, baldness and wrinkling of skin $^{30}$.Skin damage is caused mainly due to the free radicals, molecules like antioxidants present in the food it oxidizes this free radicle ${ }^{31}$. Daily intake of milk and ghee promotes health especially promotes skin complexion and brings beauty to the body.

Table2:Some daily useable Dinacharya procedure combinations of drugs

\begin{tabular}{|c|c|c|}
\hline Si no & Dinacharya & Daily useable combinations \\
\hline \multirow[t]{2}{*}{1} & Dantadhavana & Neem $\quad$ twigs $^{32}$ \\
\hline & & $\begin{array}{l}\text { ta }(\text { Saussurealappa),Triphala }(\text { Embilicaofficinalis }+ \text { Terminaliabellirica }+ \text { Terminaliachebula }), \\
\text { Trikatu(black pepper, long pepper, zingiber officinal) }+ \text { Trijataka }(\text { clove }+ \text { cardamoms cinna- }\end{array}$ \\
\hline
\end{tabular}




\begin{tabular}{|c|c|c|}
\hline & & mon) + honey ${ }^{33}$ or available Ayurvedic Tooth Paste in market. \\
\hline 2 & Jihwa nirlekhana & Tongue scraper, which is not having sharp prepared with gold, silver, copper, and brass ${ }^{34}$. \\
\hline 3 & $\begin{array}{l}\text { Mukha } \\
\text { prakshalana }\end{array}$ & Ksheerivriksha kashaya,Ksheera (milk), Lodradi kwatha ${ }^{35}$ \\
\hline 4 & Tamboola sevana & $\begin{array}{l}\text { Jatiphala (nutmeg), Lavanga (clove), Karpoora( camphor), Kankola (Cassia fistula), Katuka } \\
\text { (Picrorhiza Kurroa) }{ }^{36}\end{array}$ \\
\hline 5 & Gandusha & Taila(Oils),Payaha(milk),Madhu(Honey),Ushnodakam(Lukewarm water) ${ }^{37}$ \\
\hline 6 & Anjana & Souveeranjana ${ }^{38}$ (Antimony sulphide), Krishna Suruma(Available in market) \\
\hline 7 & Nasya & $\begin{array}{l}\text { Anutaila }^{39} \text { (Medicated oil for Nasya Karma) or Karpasa taila (Cotton seed oil) or Ksheera- } \\
\text { balataila }\end{array}$ \\
\hline 8 & Siroabhyanaga & $\begin{array}{l}\text { TilaTaila (Sesame oil), Narikela Taila (Coconut oil), Bringa raja taila (Ecliptaalab), Neeli } \\
\text { taila (True indigo) }\end{array}$ \\
\hline 9 & Anulepana & Chandana (Sandal) or Agaru (Aquilaria agallocha) \\
\hline
\end{tabular}

\section{CONCLUSION}

Cosmetic industry is growing day by day. The technologies and industries are in the peak level of it, as parallel to this the side effect of cosmetics products craving the world as like cancer. They cause irritation, contact allergy, photosensitivity, contact urticaria, acnelfolliculitis, color change of skin and appendages, other local side effects, and some systematic side effects like nephrotoxicity, gynecomastia, and pulmonary diseases like asthma etc ${ }^{5}$. This needs an hour to think alternatives to avoid this side effect. The world will look forward to Ayurvedic traditional way of lifestyle modifications like Dinacharya, Ritucharya, procedures to maintain the harmony of life. Dinacharya has a vital role to maintaining the sound mind and body through the procedures. Dinacharya procedures which are prescribed for Oral hygiene, Healthy skin and Healthy sensory organs having great cosmetic effect and are safe, available, acceptable and affordable only needs propagation through mass media to adopt by every individual.

\section{REFERENCES}

1. https: Ilen.wikipedia.org\wiki|cosmetics.

2. Meriam, W.E.B.R.S.T.E.R. Cosmetics. [Online].

3. Kumar Narender. History of Indian concept of cosmetology -a review. IJAAR. sept- oct 2016;2(9): 12691274 .

4. Robert Alex. Ezine Articles. [Online]. Available from: https $\backslash$ Ezine.com lexpert $\ 422 \backslash 84$.
5. Harischandra Simhs Kushavaha, Ashtanga Hridaya, Sarvanga Sundari Commentary, Chowkhamba Orientalis, Varanasi. Sutrasthana.1/1, Page No.65

6. Bhava Misra Of Bhava Prakasha, English Commentary By Balusu Srinivas, Chaukhamba Orientalia, Varanasi, Dinacharya Prakarana5/307, Page No.95-96

7. Susruta Samhita, Bhaskara Govind Ghanekar, Motilal Banarasidas, ChikitsaSthana 24/26, Page.No.566

8. RK Sharma \&Bhagavan Dash, CarakaSamhita, Chaukhamba Sanskrit Series, Suthrashtana 5/18. Page No. 112

9. RK Sharma \&Bhagavan Dash, Caraka Samhita, Chaukhamba Sanskrit Series, Suthrashtana 5/72. Page No. 122

10. RK Sharma \&Bhagavan Dash, Caraka Samhita, Chaukhamba Sanskrit Series, Suthrashtana 5/78-80. Page No. 123

11. Susruta Samhita, Bhaskara Govind Ghanekar, Motilal Banarasidas, Chikitsa Sthana 40/52, Page.No.566

12. RK Sharma \&Bhagavan Dash, Caraka Samhita, Chaukhamba Sanskrit Series, Suthrashtana 527-32. Page No.114

13. RK Sharma \&Bhagavan Dash, Caraka Samhita, Chaukhamba Sanskrit Series, Suthrashtana 5/88-89. Page No.124

14. RK Sharma \&Bhagavan Dash, Caraka Samhita, Chaukhamba Sanskrit Series, Suthrashtana 5/81-83. Page No. 124

15. RK Sharma \&Bhagavan Dash, CarakaSamhita, Chaukhamba Sanskrit Series, Suthrashtana 5/94. Page No. 126

16. RK Sharma \&Bhagavan Dash, Caraka Samhita, Chaukhamba Sanskrit Series, Suthrashtana 5/95. Page No. 126 
17. RK Sharma \&Bhagavan Dash, Caraka Samhita, Chaukhamba Sanskrit Series, Suthrashtana 5/90-92. Page No. 124

18. Susruta Samhita, Bhaskara Govind Ghanekar, Motilal Banarasidas, Chikitsa Sthana 24/28, Page.No.576

19. Susruta Samhita, Bhaskara Govind Ghanekar, Motilal Banarasidas, Chikitsa Sthana 24/41, Page.No.571

20. Susruta Samhita, Bhaskara Govind Ghanekar, Motilal Banarasidas, Chikitsa Sthana 24/63, Page.No.571

21. Susruta Samhita, Bhaskara Govind Ghanekar, Motilal Banarasidas, Chikitsa Sthana 24/65, Page.No.572

22. Susruta Samhita, Bhaskara Govind Ghanekar, Motilal Banarasidas, Chikitsa Sthana 24/68, Page.No.572

23. Mohiuddin, A.K. Cosmetics in use a pharmacological review. Journal of dermatology and cosmetology. 2019;3(2):

24. Anton. C, de Groot. Adverse reactions of cosmetics. theses university of Groningen.

25. KRS Murthy, Ashtanga sangrah of Vagbhata, chaukhambha Orientalia, sutrasthana3/54-61, page no. 4243

26. Pt Hari sadasivasastri paradakara. Ashtangahridaya. Varanasi: Chawkamba sanskritsansthan; 2009. sutrasthana $1 \backslash 18$

27. Henry gray Longman. Gray's Anatomy. (35 ed.). USA: W B Sunders; 1975.pg no: 884.

28. $\mathrm{Pt}$ Hari sadasivasastri paradakara. Ashtangahridaya. Varanasi: Chawkamba sanskritsansthan; 2009.sutrasthana $1 \backslash 18$

29. Agnivesha. Sareera Sthana. Vaidya Jadavji Tikramji Acharya with Ayurveda Deepika Commentary of Chakrapani dutta, Charak Samhita. Reprint Ed. Varansi: Chaukhamba Prakashan, 2008; 7(15): 339

30. Agnivesha. Sutra Sthana. Vaidya Jadavji Tikramji Acharya with Ayurveda Deepika Commentary of Chakrapani dutta, Charak Samhita. Reprint Ed. Varansi: Chaukhamba Prakashan, 2008; 27(65): 158.

31. https://en.wikipedia.org/wiki/Antioxidant

32. Susruta Samhita, Bhaskara Govind Ghanekar, Motilal Banarasidas, Chikitsa Sthana 24/6, Page.No.578

33. Susruta Samhita, Bhaskara Govind Ghanekar, Motilal Banarasidas, Chikitsa Sthana 24/7, Page.No.578

34. SusrutsSamhita, Bhaskara Govind Ghanekar, Motilal Banarasidas, Chikitsa Sthana 24/63, Page.No.578

35. Susruta Samhita, Bhaskara Govind Ghanekar, Motilal Banarasidas, Chikitsa Sthana 24/13, Page.No.578

36. Susruta Samhita, BhaskaraGovind Ghanekar, Motilal Banarasidas, ChikitsaSthana 24/22, Page.No.571
37. Susruta Samhita, Bhaskara Govind Ghanekar, Motilal Banarasidas, ChikitsaSthana 40/64 Page.No.578

38. RK Sharma \&Bhagavan Dash, Caraka Samhita, Chaukhamba Sanskrit Series, Suthrashtana 5/15. Page No.111

39. RK Sharma \& Bhagavan Dash, Caraka Samhita, Chaukhamba Sanskrit Series, Suthrashtana 5/63. Page No. 120

\section{Source of Support: Nil Conflict of Interest: None Declared}

How to cite this URL: Ripsa Raj K. P \& P Sudhakar Reddy: Cosmetic Effect Of Dinacharya (Daily Routine) Procedures A Critical Review. International Ayurvedic Medical Journal \{online\} 2020 \{cited August, 2020\} Available from: http://www.iamj.in/posts/images/upload/4144_4150.pdf 